ISBN 978-93-86878-06-9

8th International Conference on Literature, Languages, Humanities and Interdisciplinary Studies

(LLHIS-17)

Kuala Lumpur (Malaysia) Dec. 14-15, 2017

\title{
Politeness in Conversation on TV Series Friends
}

\author{
Indrawati ${ }^{1}$, Prof. Dr. Sri Samiati Tarjana ${ }^{2}$ and Prof. Dr. Joko Nurkamto, M.Pd. ${ }^{3}$ \\ ${ }^{1,2,3}$ Sebelas Maret University, Indonesia
}

\begin{abstract}
This paper is written based on research on Politeness in Conversation found on TV Series Friends. It is conducted to fulfill one of the requirements to obtain doctoral degree in Linguistic Pragmatics. The research questions are first, what are the forms of Speech Acts and their meanings? Second, what are the functions of politeness? And third, In what way is politeness influenced by American Values? The film script functions as media from which its content is analyzed using content analysis to see how utterances give impacts on the speakers in the conversation, as well as to the audience of the film. The data were utterances of five episodes from TV Series' five seasons. The utterances were found in five speech events containing 58 utterances in the form of words or phrases or long sentences having potential characteristics to be analyzed its forms and meanings of speech acts, politeness strategies and their function while at the same time analyzed whether or not American cultural values influence politeness. The result showed that in terms of form and meaning representative speech act gives meaning to show the action to inform facts as the form of speech act is concerned 1 , to show the action of future commitment 4, to show the action of command 3, to show the speaker's psychological condition 2. Commissive speech act gives meaning to show the speaker's psychological condition 2 and to show the action of command 1. Expressive speech act gives meaning to show the speaker's psychological condition 1. The total utterances analyzed were 15 utterances. Utterances functioning as politeness utterances are those showing Agreement 11, Sympathy 2, Modesty 2 and Generosity 1. In terms of face notion, utterances showing politeness strategy were: Positive politeness with the strategy of giving attention 4 , uttered jokes 3, showed exaggeration 2, told white lies 1, included hearer as group member 1. Negative politeness with the strategy of hedge 10, using pluralization 1, bald on record 2, off record with strategy of showing ambiguity 1, contradictory 1, incomplete utterance 1. The American values that can be inferred through analyzing utterances and context in which speakers interacted in the speech event were individualism, materialism, logical thinking, freedom, independence, doing orientation, individual responsibility concerning physical health and environment, male and female differing commitment to marriage, their mutual share of establishing relationship. It can be concluded that the form of utterance may bring about particular meaning away from the nature of speech act as the analysis considers contexts of linguistic, social and culture. Positive politeness was the dominant politeness that this is obvious as the way to create harmonious relationship among the six friends in conversation in the TV series Friends. It is evident that western values are prevailing in the aspects of individualism, independence, freedom, doing instead of being orientation. All were historically handed down from generation to generation that mark the American characters.
\end{abstract}

Keywords: politeness strategy, speech acts, context, American values, TV series Friends.

\section{Introduction}

Language is an important aspect of culture by which people use as a means of communication. Through language, cultural reality is exposed and with language, people build and shape social reality (Kramsch 1993: 34 in Jumanto 2008).

All people need to communicate to each other to convey what they want to achieve either in formal or informal situations. When a person speaks, she or he has to decide choices on what to say, how to say it and what specific sentence types, words, sounds that best unite the what and the how. Communication is one of human activities that everyone recognizes but few can define satisfactory (Fiske 1990:1). While engaging in 
communication, people have to be aware of people's face with the concern of maintaining and considering each other's feelings to establish a harmonious relationship. Yule (1996: 60) stated that as a technical term, face means the public self-image of a person. It refers to emotional and social sense of self that everyone has and expects everyone else to recognize.

Language and politeness are two intertwined communication phenomena that Brown gave attention to; Brown stated that there are three definitions of politeness. First, it is a social rule for speech and behaviour stemming from high-status individuals or groups. In literate societies the rules are in etiquette books, range from polite formulae such as please, thank you, forms of greeting and farewell, table manner, department in public, protocol for formal events and the like. In other words, it is attached to linguistic forms and formulaic expressions that laymen refer to merely particular forms of words.

Second, contrary to the first statement, politeness is the conduct adherence to politeness motivated by general principles. It is seen as a set of social conventions coordinated with Grice's Cooperative Principle (Grice: 1975) of maxims of quality, quantity, relevance and manner. This means that a speaker is expected to make contribution such as required by the purposes of the conversation at the moment. When one does, Grice's maximal efficient information is fulfilled. As one of topic of main topics of pragmatics ( Lakoff,1973 in Jumanto 2008) proposes conversation rules, that is: do not impose, give options, and be friendly. In relation to realizing politeness, Leech (1983) stated ways to minimize the expressions of impolite beliefs through applying six maxims correspondingly as Tact, Generosity, Approbation, Modesty, Agreement, and Sympathy.

Third, Politeness as face management. In this respect, Goffman (1967) refers politeness as an aspect of interpersonal rituals as central to public order. His opinion is that face is an individual's manifest of self-esteem in which social members have two (2) kinds of face requirements. Positive face is the want for approval from others and negative face is the want not to offend others.

Later Goffman (1971) stated his working assumption that face is always potentially at risk so that any interactional act with a social relational dimension is inherently face threatening and needs to be modified by appropriate forms of politeness.

In the case of speakers' violate cooperative principles mentioned before, politeness utterances are realized, which are two in characters: First, Positive or Solidarity Politeness is directed to ratify the personality of the interlocutor or speaker. Politeness Solidarity is characterized by the use of intensifiers, in-group identity markers, address forms, exaggerated intonation patterns, forms of emphasizing agreement and avoiding disagreement. Second, Negative or Avoiding or Respect Politeness is directed to mitigate or minimize imposition. Politeness avoidance is characterized by the forms of expressing self-effacement, formality, restraint, deference, use of honorifics, hedges, indirect speech acts, impersonalizing mechanisms like pronoun pluralization, nominalization, passive, etc.

Dealing with politeness as face management, Brown and Levinson (1987) stated their abstract model of politeness. Human actors have two essential attributes that is face and rationality. Positive face is the desire to be approved of, admired, liked, and validated; whereas negative face is the desire to be unimposed upon, unimpeded in one's action. Rationality concerns with speakers' ability to reason from common goals to linguistic means that would achieve these goals.

Brown and Levinson assumed that speakers are able to construct and interpret polite utterances in different contexts based on three factors of abstract social dimensions of P (Power) and D (Distance) as social relationship and $\mathrm{R}$ (Rank) as cultural values and definitions of threats to face.

The proposed strategy of politeness principles are: first, avoid producing utterance altogether; second, carrying it out but off record (use indirect utterance); third, bald on record without redressive action; fourth, carrying it out with positive redress addressing positive wants emphasizing closeness and solidarity; and fifth, carrying it out with negative redress addressing negative wants emphasizing distance, deference, freedom of imposition. 
There are three levels of Face Threatening Acts/ FTA: a) low level of FTA threat which speakers use bald on record and positive politeness which is appropriate and cost effective; b) higher level of FTA threat in which speakers use negative politeness; and c) highest level of FTA in which speakers use indirect utterances.

Realizing politeness is in accordance with the application of various speech acts. Speech Act theory was first introduced by Austin (1962) then followed by Searle (1979). Austin (1962) asserted that when a speaker says an utterance, she/he produces an action through the utterance. An utterance as an act is characterized into three: locutionary act as merely meaningful linguistic form; illocutionary act as utterance of doing an action whose meaning is deduced from context; and perlocutionary act as utterance that brings impact on the hearers.

Later on Searle (1979) proposed the category of speech act into five of which complying with dimensions of illocutionary point. They are: direction of fit, expressed psychological state, and propositional content. Searle's five speech act category is:

- Representative or assertive speech act which proposes speaker's belief in truthfulness of proposition. Utterances of representatives are asserting, claiming, concluding, reporting, stating.

- Directive speech act which proposes speaker's wish for hearer to do. Utterances of directives are advising, commanding, ordering, questioning, requesting.

- Commissive speech act which proposes speaker's intention to do in the future. Utterances of Commisive are offer, pledge, promise, refuse, threat.

- Expressive speech act which through utterance, speaker expresses psychological conditions of either happiness or sadness. Utterances of expressive are apologizing, congratulating, praising, thanking.

- Declaration speech act whose meaning gives impact on the conditions and the hearer.

From the above description of utterances, it can be concluded that the utterances of particular speech act could be categorized as politeness formula or speech act formulaic as modelling of native speaker formula which is included in (HC) High Context utterance (Grundy, 2004). This formulaic language is by its nature idiomatic and for the most part unsuited to intercultural communication.

Related to the use of speech acts in natural intercultural context, the research that is going to be dealt with in the future is expected to concern more on the appropriate way of using English as global language to develop learner's skills in intercultural communications. The learners here refer to language learners of English as a second and foreign language whose current role is as international language spoken globally.

It is highly necessary that the most knowledgeable experts or experts of linguistics encourage the practice of focusing on (LC) Low Context utterance. LC utterance is the one in which the pragmatic value was readily understood without requiring all that much additional non- verbal information. LC enables interaction between two speakers of different first languages (Grundy, 2004: 40).

Media helps create global culture as the ideology.. As one forms of media, television and its programs disseminate the values, norms, behaviours and cultural artefacts of one culture, in this case American culture to countries worldwide including Indonesia. Television situational comedy Friends was aired on weekly bases along with intensive news and discussions of the story lines and characters that the film and its actors became the idols of the Indonesian audience. Apart from its talented actors and actresses, the film was highly acclaimed for its brilliant conversations in which characters interchange to build harmonious relationship with one another during the course of the story. Indonesian audience find difficulties comprehending the meaning of some expressions although they are carried away into loud laughs following the can-laughter played by film producers to create laughter.

This study assumes that speech acts is realized with the influence of social norms of the speakers that is American culture. The level of speech acts mediates immediately between grammar and speech event and speech situation in that speech acts implicate both linguistic form and social norms (Hymes 1972:57) 
The comprehension of conversation of TV series Friends is obtained through understanding the forms and meanings of utterances or speech acts in various contexts and understanding the function of politeness as well as understanding the influence of American value on politeness.

\subsection{American Culture}

The basic values began to define the American character in the late 1700's. The rights people have, the history, the reasons why people from around the world emigrated to the United States explained the reasons of American people's peculiar and particular characters.

American Dream is an unofficial philosophy of Americans; however, its role is influential as the American characteristics are stated in the American Dream. That being an American is a big part of who American people are. There are prevailing values of American character; they are independence, individualism, freedom, selfreliance, equality of opportunity, competition, material wealth, hard work, and many more which people believe. Yet, those values do not tell the whole character, they are one of facets of the character and life of Americans.

The things as obviously American's as food, sport, music, fashion and many more. are only on the surface; however, below this surface there are less obvious cultural values that dictate how American people behave (ePluribus America online Culture Magazine).

\subsection{Situational Comedy Friends}

Friends is American television series on the NBC channel that aired for ten seasons from 1994 to 2004. Friends is a comedy series and filming took place in front of a live studio audience. Situational comedy, such as Friends commonly lasts for about 22 minutes per episode. Each episode consists of multiple storylines in which problems are solved during the course of one episode. The series revolve around an ensemble of six friends in their mid-twenties: Monica Geller, her brother Ross Geller, Phoebe Buffay, Joey Tribbiani, Chandler Bing and Rachel Green who all live in Manhattan.

The show became immensely popular with the public, has received many award nominations, and wins among which is British BAFTA award in 1998, Emmy Award in 2001, Golden Globe in 2003. The series finale was the decade's most watched television show. The film that was created by David Crane was said to be successful because of lively conversation exchange that can be explained through pragmatic analysis. This refers to the concerns of pragmatics as the study of finding the speaker's meaning in uttering utterances through the exchange that takes place amongst the characters.

\subsection{Ideology in Media}

Television is one of media that enables to change the process of cultural orientation of norms and values and behaviour of a society. Marshall (2007: 10-15) stated that television functions to maintain ideology in a society. Ideology is the knowledge of ideas. Ideology is the mental framework-the language, the concept of categories, imagery of thoughts and the system of representation that are used by dominant social classes to make sense of, define, figure out and render intelligible the way society works.

Television producers spread ideology about American ways of life, characters and personality traits through creating situational comedy Friends that was aired intensively each week for the period of ten years.

\section{Methodology}

This research employs content analysis focusing on rhetorical analysis based on utterances identification approach to draw inferences to find out the form and meaning of utterances, functions of politeness and influence of American values on politeness. The process of analysis in drawing inferences is done considering the context of situation, social and culture that blanket the utterance. Abductive inference is used that analysis considers the one entity of a domain to be processed with other entity of other domain to answer the problems of this research. The findings were verified using essay type questionnaire of completion filled by students of 
English Department of Semarang State university to confirm about whether or not American culture influences the politeness as well as the existence of that culture on the viewers/audience in Indonesia.

\section{Analysis and Discussions}

Below are data of utterances in speech event from episode 17 season 5 and their analysis and discussion.

Utterance (2) Hey! What's up? is an utterance shows positive politeness showing interest as strategy. The speaker (Rachel) greets her friends happily. As explained in the theory of politeness of face notion, the meaning of speaker's utterance is sharing good news or happiness that she feels, as judged from context of conversation, Good. Other clue is her gesture and facial expression in saying the greeting.

Utterance (3) Well, I have a job interview at Ralph Lauren tomorrow. It is an utterance of representative speech act with the meaning of commissive. The word well is hedged of negative politeness to soften effect. Representative utterance shows that speaker informs the true fact that she was called to have an interview. The meaning; however, is commissive. This means that speaker will attend the interview tomorrow.

Utterance (4) Congratulations! Ohh, that's great! uttered by all of her friends shows that they show positive politeness with exaggerating strategy. This implies the speakers' way of showing support and happiness to Rachel for having an opportunity to attend the interview. This positive politeness is meant to fulfil the positive need of Rachel of being recognized and approved by her friends.

Utterance (6) Anyway. I'm going to be the coordinator of the woman's collection. I'll work right under the director, It's the perfect, perfect job for me shows commissive utterance which means that the speaker is entitled to do the activity in the future as stated. The meaning remains the same. However; the word anyway shows negative politeness with strategy hedged. The speaker is meant that her utterance will not sound too arrogant of self- praise.

Utterance (7) Wow! Well, if you nail the interview, you'll get it. The hedged Well is negative politeness that the speaker intends to soften imposition of her next utterance: If you nail the interview you'll get it. Perform the best in an interview is something hard to do that the speaker tries to minimize threat of failure given that the hearer performs the other way round.

Utterance (8) Yeah and (10) O-Okay, (11) Hi show maxim of agreement, the speakers minimize disagreement with other and maximize agreement with others.

Utterance (13) Very good handshake, good wrist action shows positive politeness of exaggerating strategy. This utterance provides the hearer's recognition of doing something well.

Utterance (15) Okay shows the maxim of politeness of agreement in which the speaker, Phoebe, agrees to practice shaking hands with Monica.

The next utterance (16) Oh My God! What did I ever do to you?! is interrogative utterance meaning of expressive, Phoebe's psychological or physical condition of pain as Monica squeezed Phoebe's hand too hard.

Utterance (17) Let's just say, I'm glad I'm not Chandler which means that the speaker (Phoebe) uses positive politeness with strategy of joking to maintain the hearer's or Monica's positive face not to be embarrassed for squeezing the speaker's hand too hard. Chandler is Monica's fiancé. If Phoebe had been Chandler, Monica would have squeezed her even harder, in which the context was that two lovers may show excessive love through physical contact and expression.

\section{Conclusion}

From the above analysis of utterances found in episode 17 season 5, there are three forms of utterances: The representative utterance (3) with commisive meaning of doing activity in the future, the commissive utterance (6) shows real meaning as the form of utterance and (16) is interrogative utterance showing the meaning of expressive which means showing the psychological condition of the speaker. 
The politeness maxim are utterance (2) positive politeness of interest strategy and utterance (4) positive strategy (13) of exaggerating strategy. Utterances (8) (10) (11) (15) show maxim of Agreement. Utterances (3) (6) (7) show negative politeness. Utterance (17) shows positive politeness of joking strategy.

As it was stated above, the speech event consists of 17 utterances with the following explanation: there are 3 speech acts of form with their different meanings; there are 4 utterances with positive politeness, and 4 utterances showing maxim of Agreement. There are 3 negative politeness of hedged performative.

The American value observed was achievement and ways towards success. The future job in fashion industry promises financial security. Materialism means both ownership of goods and power of money. This is undoubtedly inheriting the protestant ethic, that wealth is godliness.

This research has analysed the other four speech events, however, due to the space, they were not included and presented in this paper.

\section{Acknowledgements}

I would like to express my deepest gratitude to the committee of the 8th International Conference On Literature, Languages, Humanities and Interdisciplinary Studies in Kuala Lumpur who gave me the opportunity to present this paper on the topic of Politeness on TV Series Friends, which will help me enrich my deeper knowledge on linguistic pragmatics through discussion with other highly profile experts in this field, about presenting paper, analysing the problems and composing the language of an academic knowledge. I would also like to present my gratitude to the university of Surakarta Sebelas Maret for providing me with the opportunity to deeper my education in Linguistic Pragmatics; my deepest gratitude also goes to my promotor Prof. Dr. Sri Samiati Tarjana and my co-promotor Prof. Dr. Joko Nurkamto, M.Pd for their sincere and helpful supervision.

\section{References}

[1] Austin, J.L. How To Do Things With Words. Oxford: Oxford University Press, 1962.

[2] Brown, Penelope and Stephen C. Levinson. Politeness: Some Universals in Language Usage. Cambridge: Cambridge University Press, 1987.

[3] Brown, Penelope. Politeness and Language. Max Planck Institute of Psycholinguistics, Nijmegen: Elsevier Ltd, 2015.

[4] Fiske, John. Introduction to Communication Studies. London: Routledge Print, 1990.

[5] Grice, H. Paul. Logic and Conversation dalam Peter Cole dan Jerry Morgan (ed). Syntax and Semantics, Speech Acts, 3. New York: Academic Press, 1975.

[6] Grundy, Peter. Methodology and the Pragmatics of English as an International Language. The Journal of Asia TEFL. Vol 1 No 1 pp 23-45, 2004.

[7] Hymes, D. On Communicative Competence. In J.B. Pride \& J. Holmes (Eds.), Sociolinguistics. London: Penguin, 1972.

[8] Jumanto. Komunikasi Fatis di Kalangan Penutur Jati Bahasa Inggris. Semarang: WorldPro Publishing, 2008.

[9] Leech, Geoffrey. Principles of Pragmatics. London: Longman, 1983.

[10] Marshall, L. (2007). Retrieved Agustus 18, 2017, etd.ohiolink.edu:

Available: https://etd.ohiolink.edu/rws_etd/document/get/bgsu1182538485/inline

[11] Searle, John R.. “A Taxonomy of Illocutionary Acts” dalam A.P. Martinich (ed). 1996. The Philosophy of Language. New York dan Oxford: Oxford University Press, 1979.

[12] Yule, George. Pragmatics. Oxford: Oxford University Press, 1996.

[13] ---- Understanding US Culture and Defining American Culture . www.youtube.com. e Pluribus America online Culture Magazine. Retrived January 2017 